$A, B, C$ 点はそれぞれ接着開始， 0.5 卷目接着 1 巻目 接着に対応する点である。

鼓形コイルバネの接着前のバネ定数 $\mathrm{k}$ は(28)式から

$k=\underset{64 n R_{2}^{3}}{G d^{4}} \cdot \frac{35}{5+6\left(R_{1} / R_{2}\right)+8\left(R_{1} / R_{2}\right)^{2}+16\left(R_{1} / R_{2}\right)^{3}}$
従ってこのバネの最大コイル半径 $\mathrm{R}_{2}$ と等しいコイル半 径を有寸る円筒形コイルバネのバネ定数 $k_{0}$ ととの比は

$$
\begin{aligned}
& \frac{k}{k_{0}}=\frac{35}{5+6\left(R_{1} / R_{2}\right)+8\left(R_{1} / R_{2}\right)+16\left(R_{1} / R_{2}\right)^{3}} \\
& \text { となる。この関係を第 } 9 \text { 困に示す。 }
\end{aligned}
$$

\title{
円筒形コイルバネ設計に関するアンケート の整理結果について
}

バネ技術研究会設計分科会

\section{I ま え が き}

標題のアンケートは，バネ技術研究会が円筒形コイル バネの設計基準立案に先立ち，昭和30年の初頭に陉こな ったもので，全国のバネ使用者和よび製造者が当時どの ような方法によってバネを設計しているかを知ることが
その趣旨であった。配布数 200 に対して 77 の回答が得ら れ，それを蒐集整理したところ興味ある結果が得られた ので, 事はいささか旧聞に属するが, 何等か読者の御参 考になればと，敢えて揭載する次第て市る。

\section{II 整 理 結 果}

質問 1 バネの種類について

貴社で設計又は製造されているコイルバネの種類扣よ

$N$ : 有效巻数

$\alpha:$ ピッチ任度

び使用目的を簡単に列記して下さい。

$W:$ 荷重 $\mathrm{kg}$

$\delta:$ たねみ $m$

$\tau:$ 放じり応力 $\mathrm{kg} / \mathrm{mm}^{2}$

$T:$ 回転少 $\mathrm{kg} \cdot \mathrm{mm}$

$\theta:$ 回転隽 $\mathrm{rad}$

$\sigma:$ 曲将応力 $\mathrm{kg} / \mathrm{mm}^{2}$

$2 \cdot 2$ バネの荷重，たわ文，忘うの許算式として下 記(第 1 表)の式を使用していますか。使用の場合○印, 使用しない場合×印をつけて下さい。もし別の式を使用 される場合にはその式をそれぞれ余白部に記入して下さ 认。 第 1 表

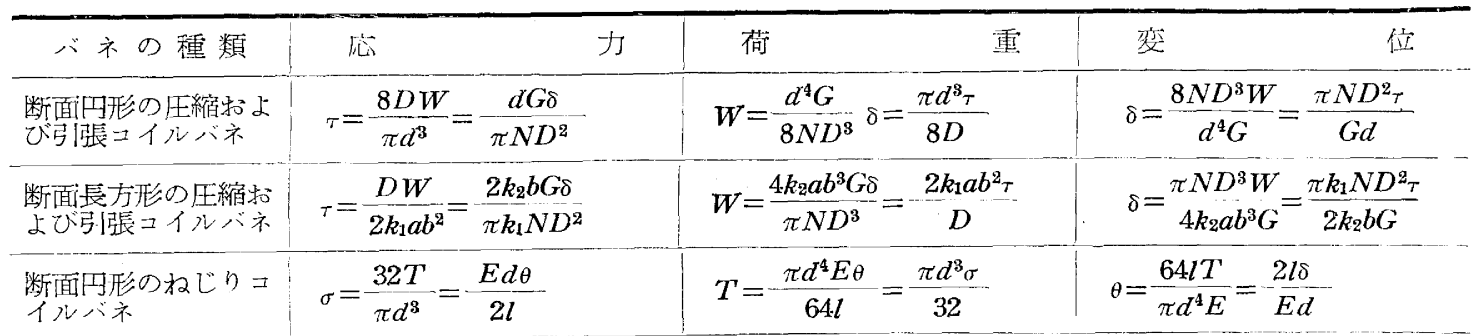

注 $k_{1}, k_{2}$ は機械工学便覽第 4 編材料力学 98 頁第 146 図参照 
回答 第 2 表参照

第 2 表

\begin{tabular}{|c|c|c|c|}
\hline バネの 種 類 & 力 & 重 & 変 \\
\hline $\begin{array}{l}\text { 断面冈形の死縮劣よび } \\
\text { 引涱コイルバネ }\end{array}$ & 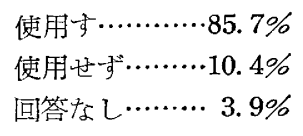 & $\begin{array}{l}\text { 使用す………. } 89.6 \% \\
\text { 使用せすき…….. } 3.9 \% \\
\text { 回答なし…….. } 6.5 \%\end{array}$ & 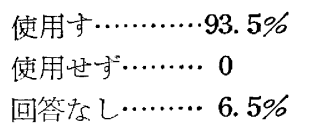 \\
\hline $\begin{array}{l}\text { 長方形断面门压縮招よび } \\
\text { 引㖘コイルバネ }\end{array}$ & 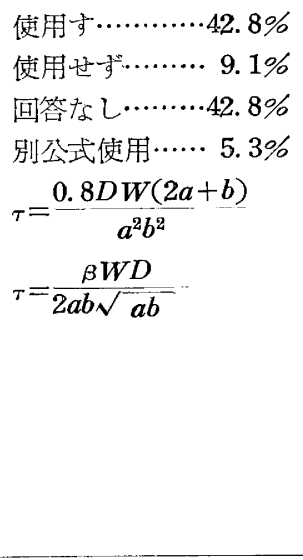 & 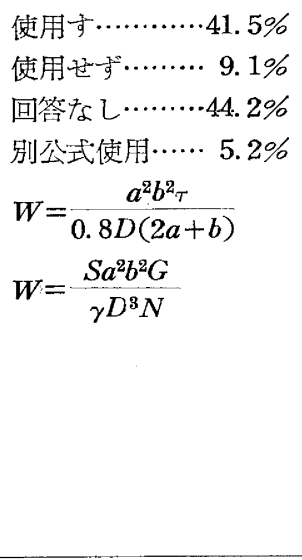 & 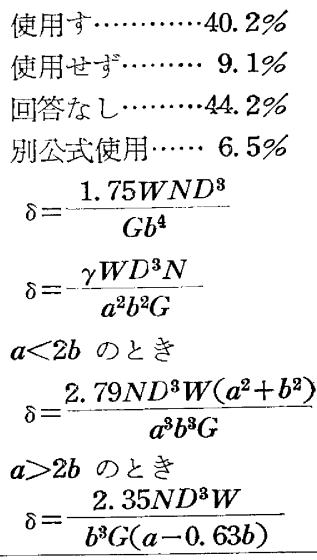 \\
\hline $\begin{array}{l}\text { 断面円形の放じりコイル } \\
\text { バネ }\end{array}$ & $\begin{array}{l}\text { 使用す............... } 4.8 \% \\
\text { 使用せず…...... } 6.5 \% \\
\text { 回答なし.......... } 45.5 \%\end{array}$ & 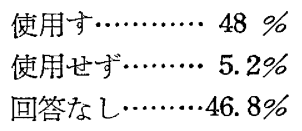 & 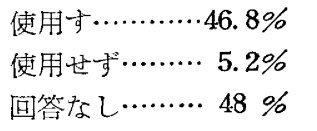 \\
\hline
\end{tabular}

$2 \cdot 3$ 使用材糊の種別による $E$ および $G$ の值をいく らにとっていますか。

$G$ に対する回答は第1図に示す。

$E$ に対する回答

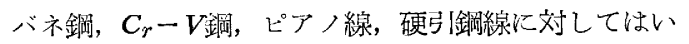

ずれもも $2.1 \times 10^{4} \mathrm{~kg} / \mathrm{mm}^{2}$ もしくはこれに近い值。

ステンレス鋼に対してはつぎの值が各 1 回答ずつあっ

た。(単位は $\mathrm{kg} / \mathrm{mm}^{2}$ )

$1.55 \times 10^{4}, 1.7 \times 10^{4}, 1.8 \times 10^{4}, 1.55 \sim 2 \times 10^{4}$

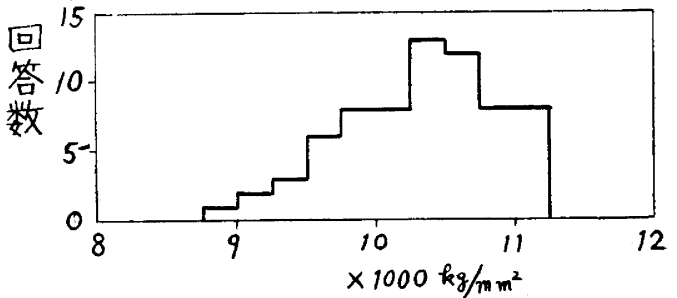

第2図 リン青銅線の $\mathrm{E} の$ 值

リン青銅線のEK対する回答は第2园に示す。

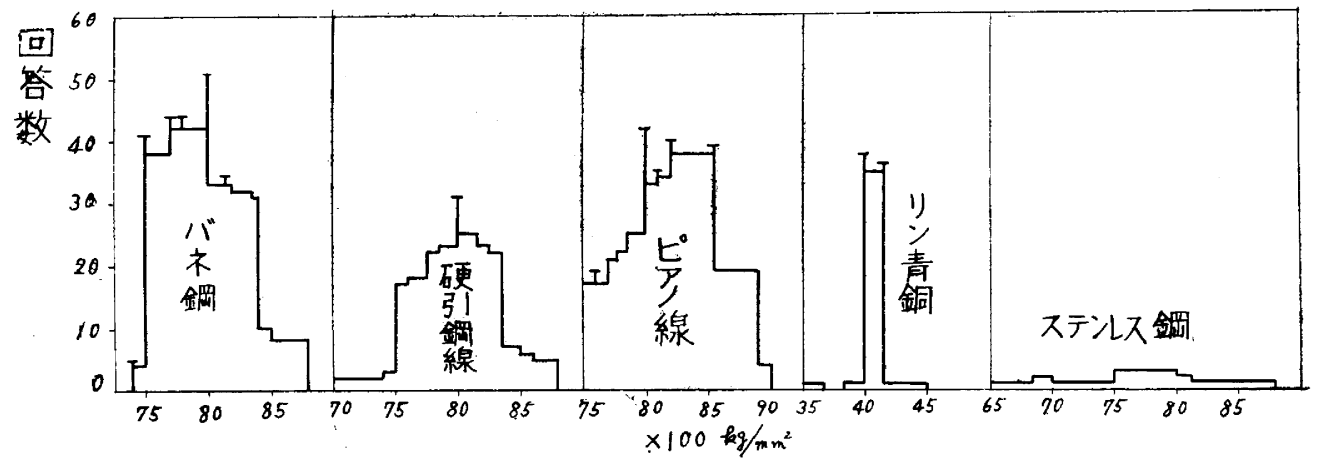

第1図 $G \quad$ 值 
2.4 総巻数 $N_{t}$, 完全巻数 $N_{p}$, 自由巻数 $N_{f}$, 有効 巻数 $N_{a}$ をそれぞれどのように定義していますか。

$N_{t}$ ：（例兄ば, 巻数の総数文は巻始めから巻終りま での巻数)

$N_{p}$ ：（例えば，断面正常の部分の巻数）

$N_{f}$ ：(例宇ば，压縮バネに拀いて $N_{t}$ より密着巻数 を除いた巻数 $)$

$N_{a}$ ：(例兄ば，バネ定数を計算する基濋になる巻数） 丈これらの間の関係をどのよう飞定めてい末すか。 定義似坟与る回答

$$
\begin{aligned}
& N_{t} \text { : 例示の通り………62 (80.5\%) } \\
& \text { その他…………... 2 (2.6\%) } \\
& \text { 国答なし…………13 }(16.9 \%) \\
& N_{p} \text { : 例示の通り………29 (37.6\%) } \\
& \text { その他………...... } 2(2.7 \%) \\
& \text { 使用せず…………… } 7 \text { (9.1\%) } \\
& \text { 記入なし….............39 (50.6\%) } \\
& N_{f} \text { : 例示の通り………21 (28.0\%) } \\
& \text { その他…………… } 8 \text { (10.7\%) } \\
& \text { 倞用せず…………... } 9 \text { (11.9\%) } \\
& \text { 記入なし………......37 (49.4\%) } \\
& N_{a} \text { : 例示の通り………35 (45.4\%) } \\
& N_{f} \text { と混同……..... } 7 \text { (9.1\%) } \\
& N_{a} \text { 之淔同 ……..... } 3 \text { (3.9\%) } \\
& \text { その他……………16 (20.8\%) } \\
& \text { 記入なし.………....16 (20.8\%) }
\end{aligned}
$$

巻数の間の関係汇ついての回答

回答のあるもの

回答のないるの….......28 (36.3\%)

\section{回答の内訳}

1. 式を示したもの ………...43

2. JIS によるとしたもの ․ 3

3. その他 ………………... 3

式の内签

$$
\begin{aligned}
& \text { (i) } N_{a} \text { と } N_{t} \text { の関係 } \\
& N_{t}=N_{a}+1 \frac{1}{2} \ldots \ldots \ldots \ldots \ldots \ldots \\
& N_{t}=N_{a}+2 \cdots \cdots \cdots \cdots \cdots \cdots \cdots \cdots \cdots \cdots \\
& N_{t}=N_{a}+2.5 \cdots \cdots \cdots \cdots \cdots \cdots \\
& N_{t}=N_{a}+3 \ldots \ldots \ldots \ldots \ldots \ldots .4 \\
& N_{t}=N_{a}+3.2 \cdots \cdots \cdots \cdots \cdots \cdots
\end{aligned}
$$

(iii) $N_{a}$ と $N_{f}$ の関係

$$
\begin{aligned}
& N_{a}=N_{f}+1 / 2 \cdots \cdots \cdots \cdots \cdots \cdots \cdots \\
& \mathrm{N}_{a} \fallingdotseq \mathrm{N}_{f} \ldots \ldots \ldots \ldots \ldots \ldots \ldots \ldots .2
\end{aligned}
$$

(iv) $N_{t}$ と $N_{f}$ の関係

$$
\begin{aligned}
& N_{t}=N_{f}+21 / 2 \cdots \cdots \cdots \cdots \cdots \cdots \cdots \cdots \\
& N_{t}=N_{f}+3 \cdots \cdots \cdots \cdots \cdots \cdots \cdots \cdots
\end{aligned}
$$

(v) $N_{f}$ と $N_{p}$ の関係

$$
N_{f}=N_{p}-1 \ldots \ldots \ldots \ldots \ldots \ldots . \cdots \cdots
$$

(vi) $N_{a}$ と $N_{n}$ の関係

$N_{p}=N_{a}+1 / 2 \quad \cdots \cdots \cdots \cdots \cdots \cdots \cdots$

$2 \cdot 5$ たわ夕と応力の計算式の修正法

$2 \cdot 5 \cdot 1$ 横弾性俰数 $G$ を計算式の諸要素（例总ば 線径 d) 比対して数值を変えていますか。

(1) 変兄ている

(口) 変えていない

(价回答なし

変えている場合にはどのような数值または式あるいは図 表を使っていますか。

(1) 2 ・ 3 亿示寺通りとして記入なきもの……9

(a) JIS F0503によるもの………………... 9

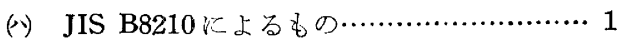

$\Leftrightarrow$ JIS G3522 とよるもの………………... 1

(休) 図表を使用するもの…………………………8

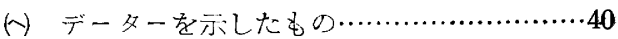

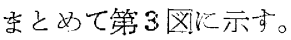

$2 \cdot 5 \cdot 2$ 貴社のバネの Spring Index $C(=\mathrm{D} / \mathrm{d})$

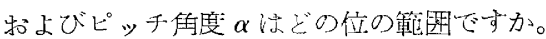

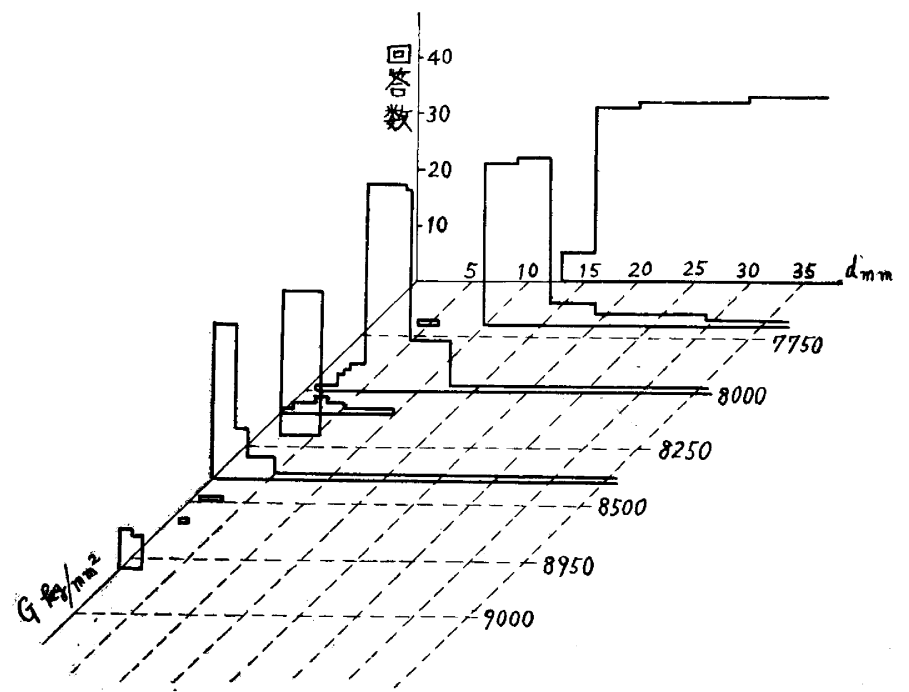

第 3 図 線径以上るGの変化 


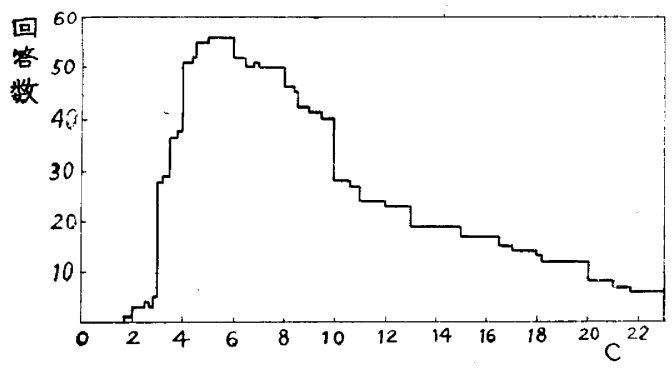

第4図 Spring index $C$ の分有

Spring Index $C$ (第 4 区参照)

回答数. $66(85.8 \%)$

回答なし $11(14.2 \%)$

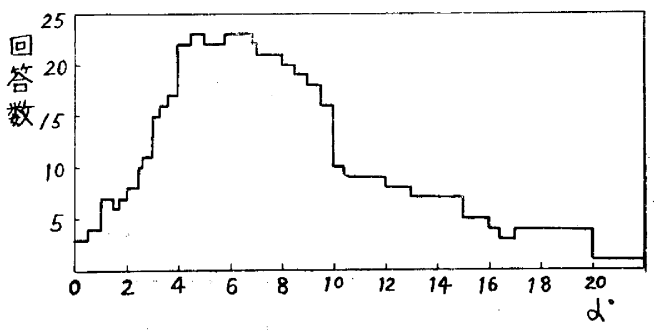

第5図ピッチ任 $\alpha$ の分布

ピッチ角度 $\alpha$ (第 5 図参照)

回答数. $34(44.1 \%)$

回答なし $43(55.9 \%)$

2・5・3 Spring Index $C$ の影響を考慮に入れて いますか

イ.考慮に入れている $45(58.5 \%)$

ロ. 考慮に入れていない $10(13.0 \%)$

八. $C<\square$ の時は考慮に入れている‥16 (20.8\%)

二, 回答なし

考慮に入れているときはどのような補正項を使用し末す 力。

回答数………62 (80.5\%)

(1) 応力に対してのみ補正項を使用するもの $52(83.9 \%)$

Röver.........32 (61.5\%), Wahl...7 (13.5\%)

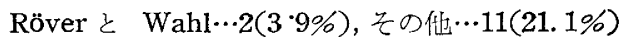

(2)地力とたわみに補正項を使用するもの $\cdots 4(6.5 \%)$

(3) 補正項を使用せず応少を減らするの……3(4.8\%)

(4) 記入なし….............

$2 \cdot 5 \cdot 4$ ピッチ角度 $\alpha$ の影響を考慮に入れていま 寸か。
イ.考虑に入れている。

$11(14.3 \%)$

ロ. 考慮に入れていない。

$4.7(61.0 \%)$

八. $\alpha>\square$ の時は考慮に入れている…7 (9.1\%)

二回答なし

$12(15.6 \%)$

考虑以入れるときはどのような補正項を使用しますか。

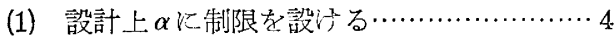

(2) 補正項を使用する。

$$
\begin{aligned}
& \frac{\frac{1}{1-C^{-1}}+\frac{1}{4} C^{-1}+\frac{1}{16} C^{-2}}{1+\frac{\frac{3}{16} C^{-2}}{1-C^{-2}}} \cos \alpha \cdots \cdots \cdots \cdots \cdot 2 \\
& \frac{\cos \alpha}{1+\frac{\cos ^{4} \alpha}{C^{2}-1}}+\frac{2 G}{E} \sin \alpha \tan \alpha \cdots \cdots \cdot 1
\end{aligned}
$$

(3) その他 4

$2 ・ 5 ・ 5$ 压縮バネの細長比入を考慮に入れていま すか。

イ. 考慮以入れている。………..29 (37.6\%)

口. 考慮に入れていない。………18 (23.4\%)

八. $\lambda>$ 四のとき考慮に入れる……18 (23.4\%)

二. 回答なし

$12(15.6 \%)$

考慮に入れるときはどのような対策をとってい屯すか。

(1) 設計上 $\lambda$ に制限を設訂る。

\begin{tabular}{c|c|c|c|c|c}
\hline$\lambda$ の徝 & 3 & 3.5 & 4 & 4.5 & 5 \\
\hline 回答数 & 1 & 1 & 16 & 1 & 1 \\
\hline
\end{tabular}

(2) 導溝または導管を設ける…….............20

(3) 座屈を考慮する……........................ 5

(4) 座巻を 1〜1.5巻つ河, 有效巻数在 0.50 奇数倍にする。……………………... 1

(5) $\lambda>5$ のとき淔届度に考慮を抾 5。……1 1

(6) その他 …........................... 4

2 -6 荷重の偏心を考慮していますか。

イ. 考慮している $44(57.1 \%)$

ロ. 考慮していない $22(28.6 \%)$

八. 回答なし $11(14.3 \%)$

考慮しているならば偏心防止のための設計および製作 検査上どのような方法をとっていますか。

(1) 有效巻数を 0.5 の奇数倍とする。……8

(2) 総巻数を 0.5 の奇数倍とする。………..1

(3) 直角度を規定する。……………....... 14

(4) 平行度を規定する。………………. 4

(5) 両端面のグラインダー加工を指定する。…4

(6) 座巻数を多くする。……………...... 7 


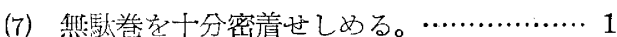

(8) バネ座に工夫を加える。……………..... 12

(9) 入を小にする。

2

$2 \cdot 7$ 組合尤バネの場合の䓟重の分担比をどのよ 5 にしていますすか。

回答数 $45(58.4 \%)$

回答な2

$22(41.6 \%)$

(1) 応力を同じくする $17(36.9 \%)$

(2) 荷重分担比をさるる $13(28.2 \%)$

（3）分担荷重をバネ定数に比例させる‥8(17.4\%)

(4) $D / d$ を一定にする

(5) 等街重分担にする

（6）組食せバネを使用せず゚

$5(10.9 \%)$

$2 \cdot 8$ 荷重, たわ文, 応力の計算に対して計算図表 を使っていまずか。
イ、俌っている $23(29.9 \%)$
口。使っていない...
$42(54.5 \%)$
八. 回答等2
$12(15.6 \%)$

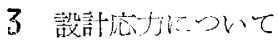

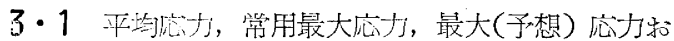
よび圧縮バネの密着時応力をどの位にとっていますか。 回答は省略する。

3.2 繰返し偖重の場合の平均応力一応力振巾一繰 返し回数支るいは赤入变形などに関する奉験データを叔 接ちでしたら告しら扱下さい。

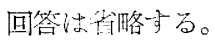

4 バネの振勘以つい

4・1 バネの重量計算はどんな方法によっています 力。

回答数 $36(46.8 \%)$

回然店2 $41(53.2 \%)$

内訳

(1) $W={ }_{4}^{\pi^{2}} d^{2} D N \rho \quad$ 文は $=19.3 N D d^{2}$ $=2.46 \times 10^{-5} \frac{\pi^{2}}{4} D N$ $26(72.2 \%)$

Nのとり方

$$
\begin{aligned}
& (1-1) N_{t}+3 \cdots \cdots \cdots \cdots \cdots \cdots \cdots \cdots \cdots \cdots \cdots
\end{aligned}
$$

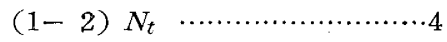

$$
\begin{aligned}
& \text { (1-3) } N_{t}-0.5 \cdots \cdots \cdots \cdots \cdots \cdots \cdot 2 \\
& (1-4) N_{t}-1 \cdots \cdots \cdots \cdots \cdots \cdots \cdots \cdots \cdot 1 \\
& (1-5) N_{t} \text {-両端重量 } \cdots \cdots \cdots \cdot \cdots \cdot 1 \\
& (1-6) N_{a}+1.5 \cdots \cdots \cdots \cdots \cdots \cdots, 4
\end{aligned}
$$

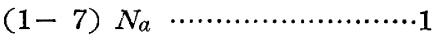

$$
\begin{aligned}
& (1-8) N_{a} \text { +画端重量 } \cdots \cdots \cdots \cdot \cdots \cdot 1 \\
& \text { (1- 9) } N_{p}+1 \cdots \cdots \cdots \cdots \cdots \cdots \cdots \cdots \\
& (1-10) N_{p} \text { 十禹端重量 } \cdots \cdots \cdots \cdots \cdot 1 \\
& (1-11) N_{f} \cdots \cdots \cdots \cdots \cdots \cdots \cdots
\end{aligned}
$$

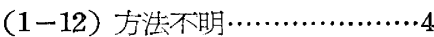

(2) $、 W=\frac{\pi^{2}}{4} d^{2} D N \frac{1}{\cos \alpha} \rho$ としてピッチ角度を考 えたもの…...............

(3) $W=\frac{\pi^{2}}{4}\left(2+\frac{n}{\cos \alpha}\right) D d^{2} \rho$ 又は

(5) その他 …............................ 3

$4 \cdot 2$ バネの固有振動数の計算法および実測值に対 する修正法はどのようにしていますか。

回答数 $28(36.8 \%)$

回答なし $48(63.2 \%)$

内訳

（1）祜含勝治 航空学会誌 7-60-293 (昭15)

$$
\begin{aligned}
& \text { によるもの } \\
& N_{f}=\text { 有効巻数 } \\
& \mu=2.31-0.14 . k
\end{aligned}
$$$$
f(\mathrm{cycle} / \mathrm{min})=1890 \sqrt{\frac{\mu k}{W}}=43000 \frac{1}{d} \sqrt{\frac{\mu k}{D N_{f}}}
$$

（2）大井上博著"葛速ディーゼル穖関”

によるもの

$$
\begin{aligned}
& f(\text { cycle } / \mathrm{min})=C \frac{d}{N_{f} D^{2}} \times 10^{5} \\
& C=216 \text { とするもの } \\
& C=215 \text { とするもの }
\end{aligned}
$$

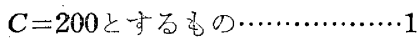

但し $d=$ 綜径 $m$

(3) $f(\mathrm{cycle} / \mathrm{min})=\frac{60}{2 \pi} \sqrt{\frac{k}{M}}$ 丈は

$$
f(\mathrm{cycle} / \mathrm{sec})=\frac{1}{2 \pi} \sqrt{\frac{g}{\delta}} \ldots \ldots \ldots \ldots \ldots
$$

但し $M=$ バネの質量 $\mathrm{kg} \cdot \mathrm{sec}^{2} / \mathrm{mm}$

$\mathrm{g}=$ 重广jの加速度 $9800 \mathrm{~mm} / \mathrm{sec}^{2}$

$\delta=$ 自重によるバネのたわみ

(4) Ricado の式尤るもの ………....

$$
f(\text { cycle } / \min )=2674 \sqrt{\frac{k}{W}}
$$


(5) Wahl の式によるもの

$$
f(\mathrm{cycle} / \mathrm{sec})=\frac{d}{2 \pi r^{2} N_{f}} \sqrt{\frac{G g}{32 \gamma}}
$$

但し $\gamma=$ コイルの平均半径 $m$

$\gamma=$ 材料の密度 $\mathrm{kg} / \mathrm{mm}^{3}$

$G=$ 材料の横弾性保数

(6) $f=\imath \frac{d}{N_{f} D^{2}} \sqrt{\frac{\mathrm{G} g \cos \theta}{2 \gamma}}$

$$
\cos \theta=\frac{1}{\sqrt{1+\tan ^{2} \theta}}=\frac{1}{\sqrt{1+\left(\frac{p}{\pi D}\right)^{2}}} \cdots \cdots 1
$$

但し $\mathrm{p}$ ニバネのピッチ $\dot{\mathrm{i}}=$ 次数

（7）三菱造船技術部研·究報告第 209 号に 上るもの

（8）空技報 0113 によるもの……...... 1

4 ・3 サージンがが閭題になる場全 設計上バネの 固有振動数に対してどのような制限をしてい末すか。

回答数 $18(23.6 \%)$

回答なし $58(76.4 \%)$

\begin{tabular}{|c|c|}
\hline 3 倍以上 $\cdots \cdots \cdots \cdots \cdot \cdots \cdot 2$ & 4 倍以上 $\cdots \cdots \cdots \cdots \cdots$ \\
\hline 倍以上 $\cdots \cdots \cdots \cdots \cdots \cdot 1$ & 5.5 倍乡上 $\cdots \cdots \cdots \cdot 1$ \\
\hline 6 倍………....2 & $11 f$ \\
\hline $1 \cdots \cdots \cdots \cdots+1$ & 13 \\
\hline . $\cdots \cdots \cdots \cdots \cdots+1$ & 20 \\
\hline
\end{tabular}

内訳

エンジン最高回転数より十分高くとる $\cdots 2$

固有振動数を 14000 20000 cpm とする ‥1

4・4 サージング防止のため バネ本体に対してど のような考慮义は対策をしていますか。

回答数

回答なし $50(66.4 \%)$

内訳

(1) バネを不等ピッチにする.

(2) friction damper 使用する 3

(3) 座巻部の巻数を多くする…….......... 2

(4) 固有振動数をか克る……...............

(5) 防振ゴムを併用する………........... 2

(6) 二重バネを採用する……...............

(7) 自由高さを極力短縮する…….......... 1

（8）中心径を大きくとり安定感を与える…1

（9）密着時の応力を疲労限以下にする……1

（10）MHD 1-5を参照し 附加荷重を考 えて許签疲学安全率内になるよ5に設
計する 1

5 許容差について。バネの要目表以どのような項目 を指定してい季すか。そのうち許谷差はどの項目に指定 し，その数值をいくらにしていますか。

回答は省略する。

6 その他

6.1 压縮バネの端末の接触部ニイル長さとして次 のうち主とどれを使用していますか。

イ. 接触せず 口. 先端接触 八. $\mathrm{n}=$ 亿ル接触 これらを使用目的に応じて使い分けていますか。 使い㘧けているならばどのようにしていますか。

(1) イ。をを採用するもの………1 1 （1.3\%）

（2）口.を採用するもの………15 (19.7\%)

(3) 八。を採用するもの………37 (48.6\%) この場合の $\mathrm{n}$ の值

$1 / 8 \sim 1 / 16 \cdots \cdots 1, \quad 1 / 4 \cdots \cdots \cdots \cdots 1, \quad 1 / 4 \sim 1 / 2 \cdots \cdots 1$,

$1 / 2 \sim 3 / 8 \cdots \cdots 1, \quad 3 / 4 \cdots \cdots \cdots \cdots \cdot 6,1 \cdots \cdots \cdots \cdots$,

1 以上. $\cdots \cdots 1,1 \sim 1 \frac{1}{2} \cdots \cdots 7,11 / 2 \cdots \cdots \cdots 5$,

1. 6 以上 $\cdots 1,2 \cdots \cdots \cdots \cdots \cdot 1$,

両端で合計 3 とする゙................... 1

JIS F 0503亿彷

大多数は 1 とし時にスワリの笠定を要求される場 合性 1.5 と脰る………................

一般機械用 $0.75 \sim 1$, 懸架用, 車洮用 $1 \sim 1.25$,

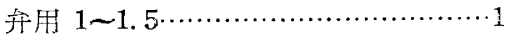

説明のないもの ……..................

(4) イロの双方を採用するもの…2 (2.6\%)

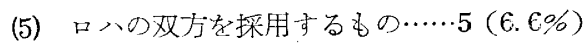

（6）イロハの全部を用途により使い分洁る bの................................

(7) 回答なし……................ 11(14.7\%)

6 -2 高温, 低温, 腐蝕性雲围気等の使用環境に対 して設計上どのような考慮を払っていなすか。

(1) 霍蝕に対する対策

リン青銅を用いる……10，ステンレス鋼を用い

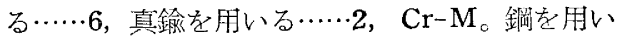

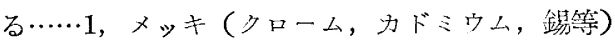

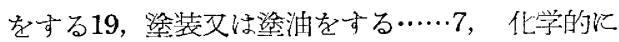
表面処理をする…… 計量部をゴムパッキン， オイルシール等にて完全密閉し外気を选断する。

(2) 高温に対する刘策 而熱鋼………2， スデンレス鋼…… $\mathrm{Cr}-\mathrm{V}$ 鋼……3，䯩速度鋼………1, 


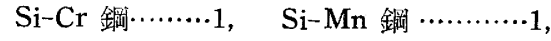

SuP $8 \cdots \cdots \cdots \cdots 1$, Oil tempered Wire $\cdots 1$,

$70^{\circ} \sim 100^{\circ} \mathrm{C}$ で縮セッ卜後使用する……1, 宸素鋼バネに刘しては設計応力るを通常の

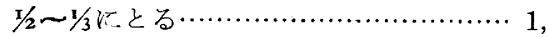
使用温度で十分セッチンがを行 $5 \cdots \cdots \cdots \cdots 1$, 熱による俯力の低下を考慮し，普通状態 で使用するものよりその分だけ初忘力を 高く設計する 1,

(3) 低温に刘する刘策

回答なし

又このような使用環境と試験環境との相異について はどのような対策をとってい李すか。

使用環境に近い試験環境を作って試験する‥

適当な補正係数を使用する 2

本項に関し全く回答のないもの…3 $35(46 \%)$

6 ・3 引張バネの初張打の最大值の定め方をどのよ うにしてい鸾か。

(1) $P_{\circ}=\tau_{\circ} \cdot \frac{\pi d^{3}}{8 D}$ を用いて計算するい.

$$
\begin{aligned}
& \tau \text { 。の值 }\left(\mathrm{kg} / \mathrm{mm}^{2}\right) \\
& \tau_{0}=5 \sim 15 \cdots \cdots 1, \quad \tau_{\circ}=5 \sim 20 \cdots \cdots \cdots 1 \text {, } \\
& \tau_{\circ}=20 \cdots \cdots \cdot \cdot 2, \quad \tau_{\circ}=258 /\left(\frac{D}{d}\right)^{2} \cdots \cdots \cdot 1, \\
& \tau_{\circ}=\left\{\begin{array}{r}
5 \sim 15(\mathrm{~d}<3) \\
10 \sim 20(\mathrm{~d}>3)
\end{array} \cdots \cdots 4,\right. \\
& \tau_{\circ}=\left\{\begin{array}{r}
5 \sim 15(\mathrm{~d}<3) \\
10 \sim 15(\mathrm{~d}>3)
\end{array} \cdots \cdot 1,\right. \\
& \tau_{\circ}=\left\{\begin{array}{l}
10(\mathrm{~d}<3) \\
20(\mathrm{~d}>3)
\end{array} \cdots 1, \tau_{\circ}=\left\{\begin{array}{c}
5(\mathrm{~d}<1) \\
8(1<\mathrm{d}<3) \cdots 1, \\
10(\mathrm{~d}>3)
\end{array}\right.\right. \\
& \tau_{\circ}=\left\{\begin{array}{l}
40 \text { (鋼線) } \\
45(\text { 溹入鋼線 }) \cdots \cdots 1, \\
55 \text { (ピア } \cdots \text { 線 })
\end{array} \cdots\right.
\end{aligned}
$$

Spring Index $\mathrm{C}=\mathrm{D} / \mathrm{d}$ により次のごとくて。を きめる

$\begin{array}{lllllllll}\mathrm{C} & 3 & 4 & 5 & 6 & 7 & 8 & 9 & 10\end{array}$

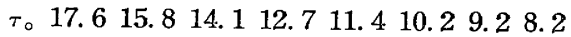

て。を許容応力の約 $1 / 4$ 以内になるように

とる……..............................

て。の值を指定していないもの……2

（2）使用最大荷重の約10にとる……2（2.6\%)

(3) 科量荷重の 2 割以内に制限する…1 (1.3\%)

(4) 最大伸長特の応力が標潗の常用最大応 力をこえざる䉐团にとる……1 (1.3\%)

(5) バネが常時たわまない程度としてあま り大きくとらない 1 (I. 3\%)
(6) $P_{\circ}=\frac{S a^{3}}{2.55 D} l b$ 但し $\mathrm{S}$ は $\mathrm{D} / \mathrm{d}$ 比によっ

て線図より求める

可管なし $58(68.5 \%)$

6・年熱間成形エイルバネ（成形後焼入，焼モドシ のるもの）の場命，焼モドシ硬さは材質预よび使用目的 に対して，どの位にとっていまずか。

（1）材質と使用目的を共に記したるの

車両用 SuP 4: 352 4.15)

獎架用 SuP $6: 420 \sim 477\}$

静份重用 SuP 5 - 6:440 -480

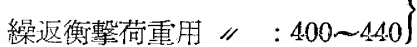
1

(2)材臂のみを記したもの

岸素銅 : 44.4 以下

合金鋼 ; 4.77 以下 $\} \cdots \cdots \cdots \cdots \cdot 1$

SuP $4: 352 \sim 4.15 \cdots \cdots 2$, SuP $4:$ : $325 \sim 415 \cdots \cdots 1$

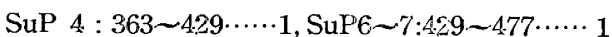

(3) 材筫も使用目的甩記してないるの

$$
\begin{aligned}
& 285 \sim 44.4 \cdots \cdots 1, \quad 341 \sim 444 \cdots \cdots 1, \quad 352 \sim 388 \cdots \cdots 1 . \\
& 375 \sim 4.01 \cdots \cdots 1, \quad 380 \sim 420 \cdots \cdots 1, \quad 380 \text { 以上 } \cdots \cdots 1 .
\end{aligned}
$$

（4）規格を示したもの

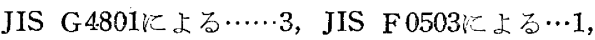
日本金嘱規格以よる……1,

(5) 回答なし.....................57 (75\%)

7 コイルバネの折損について経験されたこと扣よび その対策などを記入して下さい。 回答徒第3表

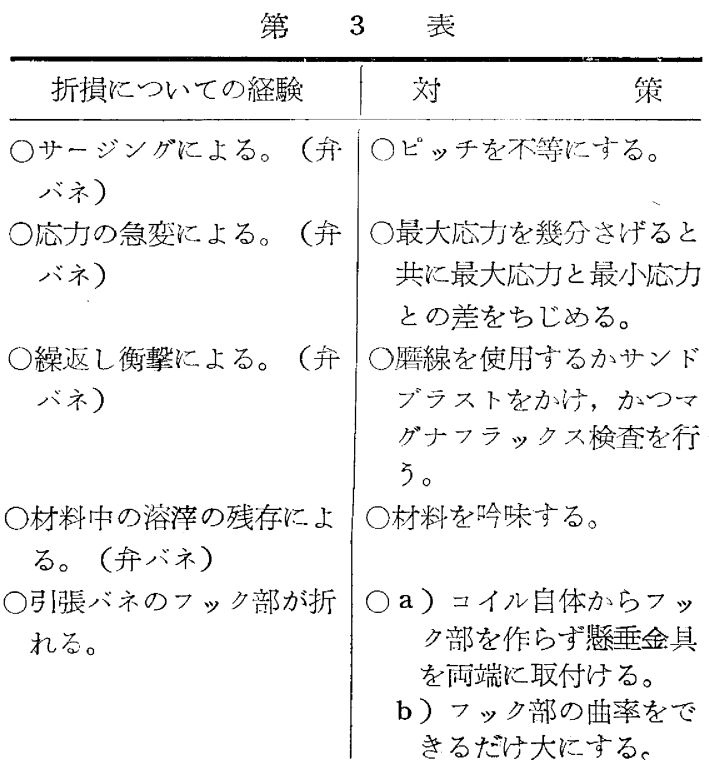




\begin{tabular}{|c|c|}
\hline 折損についての経験 & 対 \\
\hline 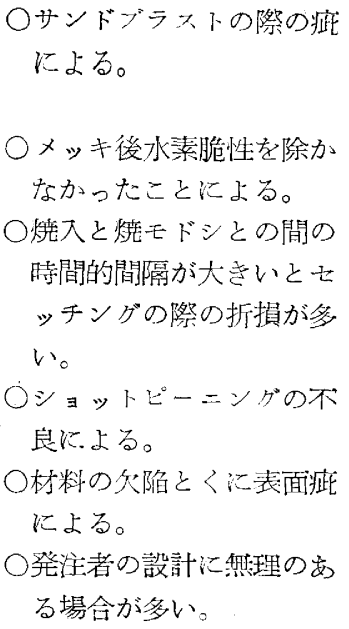 & $\begin{array}{l}\text { ○荷重条件のきびしいバネ } \\
\text { に対してはサンドブラス } \\
\text { トは行わない。 } \\
\text { ○油中煮沸によって脆性を } \\
\text { 除く } \\
\text { ○焼入した日のうちに焼モ } \\
\text { ドシする。 }\end{array}$ \\
\hline
\end{tabular}

経験をのベずに対策だけを記したもの

○表面状態を改善する。

○適正な熱処理を実施する。

○ショットピーニングを施す。

○設計上どうしても折損の危験を免れ難い場合に は，バネとして使用する前に $150 \sim 200^{\circ} \mathrm{C}$ 位の伢 中で静荷重にて締付け，バネをへたらせておく( 理由はコイルの内側の最大応力の発生する部疗に 匍匐変形を生じ，作動応力とは逆方向の残留応力 を生ずるからである)

\section{円筒形コイルバネの有效卷数に関する調查}

円筒形コイルバ不設計関するアンタートの整理結果 （別揭）に上れ添とんどすべての回答者が，円筒形二 イルバネの荷重とたわみの関係を次式によって計算して いる。

$$
\delta=\frac{8 N D^{3}}{G d^{4}} W
$$

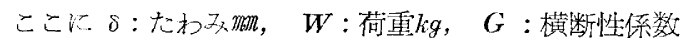
$\mathrm{kg} / \mathrm{mm}^{2}, \quad d:$ 枋料の径m $, \quad D: \pm$ イル平均直径 $m$, $N$ : 有效巻数

ただし $G$ の值をdの大きされかかわらず一定としてい る回答者は皆然记近く, $N$ を一定とし， $G$ の值は線径に よって変わるものとしているものが大部分を占めてい る。

この点につき第 3 回設計分科会（昭和 30 年 10 月 6 日） で检討した結果これまでの調查研究に照しても，Gの值 が線径によって大きく変るとは考光られず，むしろ有効 巻数が変化すると考光た方が合理的であるとの結論に達 した。

そこで淑のような方法で調査する方針をたてた。

(1) 調査の対象とするバネは, 車両用バネ, 内然機関 用バネ, 緩衝バネ, 安全弁バネの僰類とする。

\section{バネ技術研究会設計分科会}

（2）各分類每比現在各委員会社で製作しているバネの 中から普通形状，特殊形状のるのを適当に選択して 数種類をとる。そして試料の数は同一分類, 同一種 類のバネにつき 5 ケずつとする。

(3) 下記事項の測定特よび計算を行なう。

(i) 材料の直径 $\mathrm{d} \pi m$

（ii）全たわ量（自由㸗さ一一全生縮高さ）を 5 等分し $\delta_{1} \sim \delta_{4}$ に特汁る荷重 $W_{1} \sim W_{4}$ を測定す る。

（iii）各測定位置 $\left(\delta_{1} \sim \delta_{4}\right)$ に和汁る $D, N_{t}$ (総巻数) 打よび $N_{f}$ (自由巻数) を測定する。ただし $\mathrm{N}_{f}$ の測定はスキ見ら゙ージの最も薄いるのを用いて接 触点を判断する。

(iv) 各測定位置 $\left(\delta_{1} \sim \delta_{4}\right)$ と括ける $\delta ， W$ 特よび $D$ から $G=8,000 \mathrm{~kg} / \mathrm{mm}^{2}$ として公式から有效巻数 $N$ を逆算する。

この実験結果を整理してみると点のバラッキが非常に 多く, 一つの式にまとめることが困難であった。その原

*小玉正雄 "ュイルバネの横弾性係数についでバネ 論交集第 3 号 1955 